\title{
Osmotic Dehydration Process Study With Complementary Banana Peel Drying
}

\author{
Josinaldo Ferreira da Silva Júnior, Ângela Maria Santiago, Pablícia Oliveira Galdino \\ State University of Paraíba, Brazil
}

\author{
Newton Carlos Santos \\ University Federal of Rio Grande do Norte, Brazil
}

Sâmela Leal Barros

University Federal of Ceara, Brazil

Raphael Lucas Jacinto Almeida

University Federal of Rio Grande do Norte, Brazil

Israel Luna Alves

University Federal of Rio Grande do Sul, Brazil

\section{Pluvia Oliveira Galdino}

University Federal of Campina Grande, Brazil

Wanda Izabel Monteiro de Lima Marsiglia

State University of Paraíba, Brazil

Cecília Elisa de Sousa Muniz, Mércia Melo de Almeida Mota

University Federal of Campina Grande, Brazil

Received: Feb. 1, 2020

doi:10.5296/jas.v8i4.16347
Accepted: Feb. 20, 2020 Published: Aug. 13, 2020

URL: https://doi.org/10.5296/jas.v8i4.16347 


\section{Abstract}

The present study aims to perform combined osmoconvective and convective drying processes on banana peel and evaluate the influence of these processes on their physical and physical-chemical properties. A factorial planning of $2^{2}+3$ central points was carried out to evaluate the effect of the input variables: sucrose concentration varying between 40 and $60{ }^{\circ}$ Brix and temperature between 40 and $60{ }^{\circ} \mathrm{C}$, on the response variables: loss of water and mass and gain of solids in the banana peels. The drying kinetics was performed at $60{ }^{\circ} \mathrm{C}$ and empirical mathematical models were adjusted to the experimental data. The fresh peels, osmotically dehydrated, after drying process (in the optimized condition) and during 30 days of storage were characterized as for the parameters: $\mathrm{pH}$, total titratable acidity (TTA), total soluble solids (TSS), TSS / TTA ratio, water content and total solids, ash, ascorbic acid, reducing sugars, color $(\mathrm{L} *, \mathrm{a} *$ and $\mathrm{b} *$ ) and water activity (Aw). The banana peels used in the experiments had a high water content and reasonable amounts of carbohydrates and ashes. The condition that showed the greatest reduction in water content and greatest gains in solids was using the temperature of $60^{\circ} \mathrm{C}$ and $60^{\circ}$ Brix, being considered the optimized. The osmoconvective dehydration process resulted in a greater incorporation of total soluble solids and higher percentages of total solids in the shells. Page's mathematical model was the one that best fitted the experimental data; the effective diffusivity of the process was $2.2 \times 10^{-8}$ $\mathrm{m}^{2} \cdot \mathrm{s}^{-1}$. And the physical and physical-chemical parameters analyzed during the storage had small changes during the period of 30 days of storage.

Keywords: experimental planning, Musa ssp, waste, storage

\section{Introduction}

The banana (Musa ssp.) is one of the most popular tropical and subtropical fruits and consumed worldwide due to its high nutritional value (Chen et al., 2019). The high demand for bananas in the fruit market generates large amounts of waste, in which the peel represents $35 \%$ of the total weight of the fruit and is generally disposed of inappropriately. This material is rich in dietary fibers and phenolic compounds, which makes them promising for a variety of applications in the food and pharmaceutical industries (Vu et al., 2019).

Sulistyawati et al. (2018) states that the application of osmotic dehydration in agro-industrial waste is an excellent alternative to add greater value to this waste. Thus, the processing of banana peels, in addition to enabling the production of a food with high added value, provides the minimization of an environmental problem that is the disposal of this waste (Panesar et al., 2016).

According to Papazoglou and Katsanidis (2019), osmotic dehydration is a process in which water is removed and solids in food are incorporated, providing an increase in the shelf life of products and improving functional and sensory attributes such as flavor, aroma and texture. The mass transfer process occurs due to the insertion of the product in a hypertonic solution and the osmotic pressure gradient between the product and the solution is the necessary driving force for the removal of water, also influenced by the permeability of the membrane (Bozkir et al., 2019; Rahaman et al., 2019). 


\section{Al Macrothink}

The use of drying processes reduce the water content to safe levels of storage, since it involves heat and mass transfers, influencing the biological activities and the chemical and physical structure of the product, depending on the conditions and drying methods applied (Almeida et al., 2020).

Given the above, researches regarding the use of residues brought about in the banana processing, especially of its peels, are fundamental both from the environmental point of view and for the development and rise of their value, making them safe food products. The present study aims to perform combined osmoconvective and convective drying processes on banana peel and to evaluate the influence of these processes on their physical and physical-chemical properties.

\section{Methodology}

Prata banana peels came from fruits selected for their apparent quality: yellow color and without black dots, obtained in the city of Campina Grande, Paraíba. The peels were subjected to an initial wash, then they were immersed in a $50 \mathrm{ppm}$ sodium hypochlorite solution for 5 minutes and finally they were washed again to remove the excess of this solution. After the sanitization process, the peels were cut manually with a dimension of $0.5 \times 3.0 \mathrm{~cm}$ and immediately submitted to the bleaching pretreatment (immersion in boiling water for 4 minutes, followed by cooling in water at a temperature of $\pm 10^{\circ} \mathrm{C}$ to avoid prolonged heat action).

\section{Factorial experimental design for osmotic dehydration}

An experimental planning $2^{2}$ was carried out with 3 replications at the central point, making it 7 assays to evaluate the influence and experimental behavior of the independent variables (input variables), sucrose concentration and temperature, on the response variables (dependent), water loss (WL), loss of mass (LM) and solids gain (SG) in osmotic dehydration.

The planning matrix, with its respective independent variables and its real and coded levels, are shown in Table 1. The effect of the independent variables on the dependent variables was evaluated by means of statistical analysis, using the computer program Statistica ${ }^{\circledR}$ version

Table 1. Planning matrix for osmoconvective dehydration of banana peels, with their respective independent variables and their real and coded levels

\begin{tabular}{ccc}
\hline \multirow{2}{*}{ Assay } & \multicolumn{2}{c}{ Independent variables } \\
\cline { 2 - 3 } & Sacarose concentration $\left({ }^{\circ}\right.$ Brix $)$ & Temperature $\left({ }^{\circ} \mathrm{C}\right)$ \\
\hline 1 & $-1(40)$ & $-1(40)$ \\
2 & $+1(60)$ & $-1(40)$ \\
3 & $-1(40)$ & $+(60)$ \\
4 & $+1(60)$ & $+(60)$ \\
5 & $0(50)$ & $0(50)$ \\
6 & $0(50)$ & $0(50)$ \\
7 & $0(50)$ & $0(50)$ \\
\hline
\end{tabular}




\section{1) Macrothink}

\section{Osmotic Dehydration (OD)}

The sucrose dehydrating solutions of concentration 40, 50 and $60{ }^{\circ}$ Brix were prepared using commercial sucrose and distilled water. The entire dehydration process took place in a greenhouse with air circulation. The sucrose solution was kept in a water bath until it reached the process temperature, only then it was added to the container containing the samples until the slices were completely immersed.

The mass and water content of the banana peels were determined periodically with 15 minutes span, until the end of osmotic dehydration, with 240 minutes (4h), time verified when the samples reached osmotic balance, with no further mass variation. For each planning experiment, the loss of mass and water content were calculated, according to the methodology described in Brazil (2008).

Mass loss (ML), water loss (WL) and solids gain (SG), were calculated using Equations 1, 2 and 3 , respectively.

$$
\begin{aligned}
& M L(\%)=\left(\frac{M_{0}-M_{t}}{M_{t}}\right) x 100 \\
& W L(\%)=\left(\frac{M_{w 0}-M_{w t}}{M_{t}}\right) x 100 \\
& S G=W L(\%)-M L(\%)
\end{aligned}
$$

where: $M_{0}$ - initial product mass $(\mathrm{g}) ; M_{t}$ - product mass at time $t(\mathrm{~g}) ; M_{0}-$ water content in the product $(\mathrm{g})$; e $M w_{t}-$ water content in the product at time $t(\mathrm{~g})$.

\section{Drying kinetics}

The banana peels in the best condition of the factorial design of osmotic dehydration were placed on stainless steel screens, and spread evenly, forming a thin layer. To start the experiment, the trays were placed in a dryer with air circulation with an air speed of $1.0 \mathrm{~m} / \mathrm{s}$, for the drying kinetics at $60{ }^{\circ} \mathrm{C}$, at the beginning and at the end of the drying the dried masses were determined and the water contents were calculated according to Brazil (2008). Through the experimental data, it was possible to calculate the values of the water content ratio (Equation 4).

$$
R X=\frac{X_{d b}-X_{\theta}}{X_{d b(\text { initial })}-X_{e}}
$$

where: $R X$ is the moisture ratio (dimensionless); $X_{e}$ is the equilibrium water content on a dry basis; $X_{d b}$ is the water content on a dry basis; $X_{d b(\text { initial })}$ is the initial water content on a dry basis. 
With the calculation of the water content ratio, the drying kinetics curve was plotted, represented by the water content ratio as a function of the drying time in minutes, applying the mathematical models (Table 2) by Page, Henderson and Pabis and Midilli to adjust the experimental data.

Table 2. Mathematical models used to describe the drying process

Model

Page

Handerson \& Pabis

Midilli

\section{Equation}

$$
\mathrm{RX}=\exp \cdot\left(-\mathrm{k} \cdot \mathrm{t}^{\mathrm{n}}\right)
$$

Note: RX: Moisture ratio (dimensionless); k: drying constant; "A", " $n$ " and "b": parameters of the models; t: drying time.

To analyze the adjustments of the mathematical models to the experimental data, the computer program STATISTICA, version 7, was used, using the non-linear regression analysis, by the Quasi-Newton method. The models were selected taking as a parameter the magnitude of the determination coefficient $\left(\mathrm{R}^{2}\right)$ and the mean square deviation (MSD) (Equation 8).

$$
M S D=\sqrt{\sum_{i=1}^{n} \frac{\left(R X_{\exp }-R X_{\text {pred }}\right)^{2}}{N}}
$$

where: $R X_{\text {exp }}$ is the water content ratio obtained experimentally; $R X_{\text {pred }}$ is the water content ratio predicted by the mathematical model; $\mathrm{N}$ is the number of observations along the drying kinetics.

The effective diffusion coefficient was determined by adjusting the mathematical model of liquid diffusion (Fick's Law) with an approximation of three terms (Equation 9) to the experimental data on the drying kinetics of banana peels, considering the uniform and the absence of thermal resistance. This model is the analytical solution for the second Fick's Law, considering the geometric shape of the banana peels as approximated to a flat plate.

$$
R X=\frac{8}{\pi^{2}} \sum_{n=0}^{\infty} \frac{1}{(2 n+1)^{2}} \exp \left[-(2 n+1)^{2} \pi^{2} D \frac{t}{4 L^{2}}\right]
$$

where: $D$ is the effective diffusion coefficient $\left(\mathrm{m}^{2} \cdot \mathrm{s}^{-1}\right) ; n$ is the number of terms in the equation; $L$ is the size of the peel; $t$ is the time (s).

\section{Physical and physical-chemical characterization of banana peel}

The banana peels in natura, osmotically dehydrated, dried (in the optimized condition) and 
with 30 days of storage were characterized according to the following parameters: total titratable acidity (TTA), total soluble solids (TSS), TSS / TTA ratio, water content, total solids and ash according to the methodology described by BRASIL (2008). The $\mathrm{pH}$ was determined by the potentiometric method. Ascorbic acid (vitamin C) was determined by the methodology described by BENASSI and ANTUNES (1998), and the reducing sugars were determined by the methodology described by Miller (1959). The water activity was determined directly on Decagon Devices' Aqualab 3TE equipment at $25^{\circ} \mathrm{C}$. The color parameters were determined using the Mini Scan Hunter Lab XE Plus spectrophotometer (Reston, VA, USA), in the Cielab color system which allowed obtaining the parameters: $L^{*}$ (luminosity); $a^{*}$, transition from green $\left(-a^{*}\right)$ to red $\left(+a^{*}\right)$; and $b^{*}$, transition from blue $\left(-b^{*}\right)$ to yellow $\left(+b^{*}\right)$.

\section{Statistical analyzes}

Statistical analyzes were performed for the experimental data in triplicate and the results were submitted to a single factor analysis of variance (ANOVA) of 5\% probability and the significant qualitative responses were submitted to the Tukey test considering the same level of significance, $5 \%$. For the development of statistical analysis, ASSISTAT software version 7.0 was used.

\section{Results and Discussions}

Table 3 shows the results of the physical-chemical characterization of banana peel in natura.

Table 3. Banana peel characterization in natura

\begin{tabular}{ll}
\hline Parameter & Mean \pm Standard Deviation \\
\hline $\mathrm{pH}$ & $5.53 \pm 0.058$ \\
Total soluble solids (Brix) & $5.75 \pm 0.050$ \\
SST/ATT ratio & $34.22 \pm 1.818$ \\
Total titratable acidity (\% malic acid) & $0.168 \pm 0.008$ \\
Ascorbic acid (mg/100g of sample) & $1.415 \pm 0.004$ \\
Water content (\% w. $\left.^{1}{ }^{\circ}\right)$ & $84.56 \pm 0.121$ \\
Ashes $(\%)$ & $1.71 \pm 0.121$ \\
Total solids $(\%)$ & $15.44 \pm 0.017$ \\
Reducing sugars (g/100g) & $4.23 \pm 0.014$ \\
Water activity (wA) & $0.966 \pm 0.001$ \\
$\mathrm{~L}^{*}$ & $56.09 \pm 0.038$ \\
$\mathrm{a}^{*}$ & $7.44 \pm 0.029$ \\
$\mathrm{~b}^{*}$ & $40.45 \pm 0.050$ \\
\hline
\end{tabular}

Note: ${ }^{1}$ wet base.

The $\mathrm{pH}$ was non-acidic, with an average value of 5.53. The same was obtained by Castilho et al. (2014) for prata in natura banana peels in the development of flour with residues of prata and maçã bananas. Viana et al. (2017) obtained a slightly lower result in relation to this parameter (5.00) in the banana of the Grande Nain variety. The total soluble solids ( ${ }^{\circ}$ Brix) value was $5.75^{\circ}$ Brix, which was considerably low comparing to the $18{ }^{\circ}$ Brix value for 
banana pulp found by Pádua et al. (2017).

The determination of total titratable acidity (TTA) quantifies the content of organic acids present in foods, with malic acid being the major contributor to the variation in acidity in banana pulps and peels. The average value found for TTA in fresh peel was lower when compared to those obtained by Leite et al. (2010), which ranged from 0.39 to $0.43 \%$, for the banana pulp of the pacovan variety in different establishments in Mossoró (Rio Grande do Norte). Due to the low content of soluble solids present in the peel, the TSS / TTA ratio, which represents the content of sweetness and ripeness of the fruit, showed lower values compared to those obtained in the fruit pulp, studied by the same author, which varied 57.55 to 64.37 .

The concentrations of ascorbic acid $\left(\mathrm{mg} 100 \mathrm{~g}^{-1}\right)$ vary according to the genotype studied. According to TACO (2011), banana peels showed low levels of vitamin compared to pulps of the prata (21.6), figo (17.5) and terra (15.7) variaty, and considerable ascorbic acid content compared to the present in the nanica banana pulp, 5.9.

The samples in natura had a high water content, $84.56 \%$, characterizing the raw material as a perishable product. Neris et al. (2018), when determining the water content in prata banana peel at the ripe stage of ripeness, obtained similar results of $81.53 \%$. These authors found ash contents between 1.52 and $1.80 \%$ in two sampling units of banana peels, corroborating with the data obtained in this research, which was $1.71 \%$.

The determination of reducing sugars showed a value above that obtained by Castilho et al. (2014) which was $2.94(\mathrm{~g} / 100 \mathrm{~g})$ for the banana peel in natura of the prata variety. This fact can probably be attributed to the stage of ripening of the fruit. Carvalho et al. (2011) worked with the Thap Maeo variety of the apple subgroup at different stages of maturation and found values of reducing sugars ranging from 0.71 to $6.01 \mathrm{~g} / 100 \mathrm{~g}$.

The water activity value (wA) found, 0.966, is below that obtained in the peel of the mandacaru fruit by Silva et al. (2019) which was 0.990.

The parameters luminosity $\left(\mathrm{L}^{*}\right)$, red $\left(\mathrm{a}^{*}\right)$ and yellow intensity $\left(\mathrm{b}^{*}\right)$ determined for the peels in natura were 56.09, 7.44 and 40.45, which physically defines the characteristics of the fruit for the stage maturation chosen, ranging from yellow-green to yellow. Analyzing the color parameter ( $\left.\mathrm{L}^{*}\right)$ in prata-anã banana peels, Astricini et al. (2015) found values of 59.34. Differences related to fruit color, can be attributed to the stage of ripeness and the variety used by these authors.

Table 4 shows the experimental values of the dependent variables, determined by means of a $2^{2}+3$ factorial design. 


\section{Macrothink}

Table 4. Factorial design of osmotic dehydration as a function of sucrose concentration and temperature

\begin{tabular}{cccc}
\hline Assays & WL (\%) & ML (\%) & SG (\%) \\
\hline 1 & 31.26 & 28.79 & 2.46 \\
2 & 50.63 & 44.00 & 6.63 \\
3 & 42.15 & 36.82 & 5.33 \\
4 & 56.91 & 50.74 & 6.17 \\
5 & 48.55 & 42.94 & 5.60 \\
6 & 49.36 & 43.52 & 5.84 \\
7 & 48.96 & 43.25 & 5.71 \\
\hline
\end{tabular}

Note: WL: Water loss; ML: Mass loss; GS: Solids gain.

Under the conditions used for sucrose concentration and temperature, it appears that the values of water loss (WL) and mass loss (ML) varied from 31.26 to $56.91 \%$, and from 28.79 to $50.74 \%$, respectively. According to the tabulated data, it is possible to verify that these values tend to increase when the highest values are used for the combination of concentration and temperature. Thus, assay 4, was the experiment that had the greatest variations in terms of response variables, WL and ML, while assay 1 was the one with the lowest values. The same behavior for water loss was verified by Porto et al. (2014), in the optimization of osmotic dehydration of seedless Crimson grapes.

The solids gain showed values between 2.46 to $6.63 \%$ and all assays, except for number 1 , expressed values above 5\%, with assays 2 and 4 being the ones that achieved the highest results, with 6.63 and $6.17 \%$, respectively. Examining factorial design, it is observed that the concentration of sucrose is the variable that has the most influence in increasing this parameter. Likewise, Castro et al. (2018), during the study of the development and sensory evaluation of osmotically dehydrated raisin guava, observed that the values of solids gains increased with the elevation of the temperature and mainly with the concentration of sucrose.

Table 5 shows the analysis of variance (ANOVA) applied to the regression of the data of the osmotic dehydration response variables: WL, ML and SG to a linear model and their respective determination coefficients $\mathrm{R}^{2}$. 
Table 5. Analysis of variance (ANOVA) of the models adjusted for the response variables

\begin{tabular}{|c|c|c|c|c|}
\hline $\begin{array}{l}\text { Variation } \\
\text { source }\end{array}$ & Fcal & Ftab & Fcal/Ftab & $\mathrm{R}^{2}$ \\
\hline \multicolumn{5}{|c|}{ Water loss (WL) } \\
\hline Regression & 15.40 & 9.28 & 1.66 & 93.90 \\
\hline $\begin{array}{c}\text { Lack of } \\
\text { adjustment }\end{array}$ & 145.00 & 18.51 & 7.83 & \\
\hline \multicolumn{5}{|c|}{ Mass loss (ML) } \\
\hline Regression & 15.56 & 9.28 & 1.68 & 93.96 \\
\hline $\begin{array}{c}\text { Lack of } \\
\text { adjustment }\end{array}$ & 202.00 & 18.51 & 10.91 & \\
\hline \multicolumn{5}{|c|}{ Solids gain (SG) } \\
\hline Regression & 17.97 & 9.28 & 1.94 & 94.73 \\
\hline $\begin{array}{c}\text { Lack of } \\
\text { adjustment }\end{array}$ & 38.00 & 18.51 & 2.05 & \\
\hline
\end{tabular}

Nota: cal: calculated; tab: tabulated.

The significance of the regression and the lack of adjustment when at $95 \%$ level of confidence can be observed by the $\mathrm{F}$ test, a fact consistent with the coefficient of determination $\left(\mathrm{R}^{2}\right)$, which in all showed values above $90 \%$, adjusting well to the mathematical model of linear regression. It appears that, for the regression all the independent variables analyzed, the value of Fc (calculated F) was greater than the value of Ft (tabulated F), therefore, the linear model was statistically significant. The regression model was statistically predictive for all response variables, presenting an $\mathrm{Fc} / \mathrm{Ft}$ ratio $<4$. The lack of adjustment was significant for all independent variables and only the variable solids gain was statistically predictive.

Figure 1 shows the Pareto diagrams generated from the factorial design, which visually express the interaction of the dependent variables on the independent ones, according to their significance and regression, during osmotic dehydration. The magnitude of the effects is represented by horizontally arranged bars and their statistical significance, at the 95\% confidence level, by the dashed line perpendicular to the bars $(p=0.05)$. 


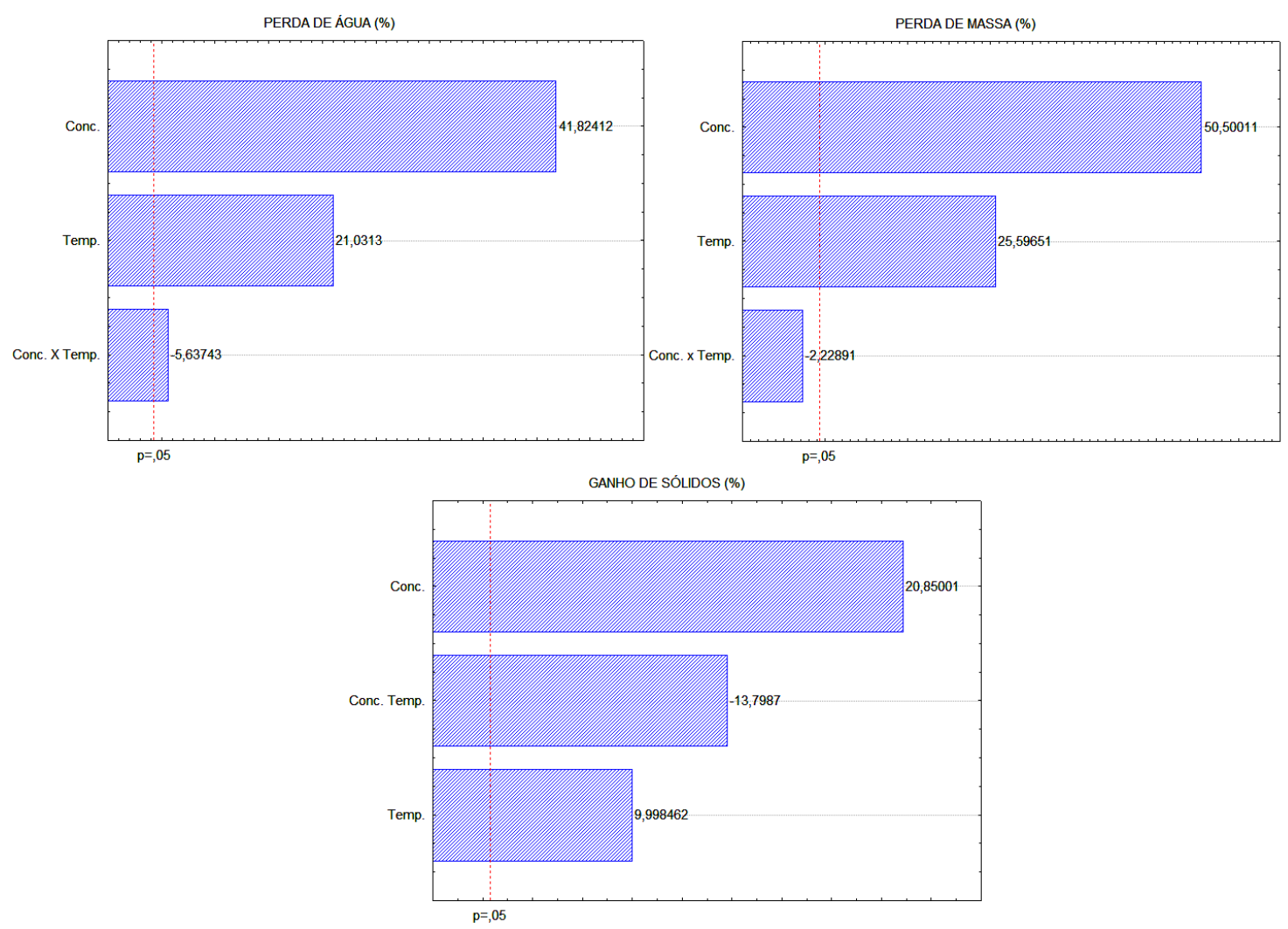

Figure 1. Pareto diagrams for water loss, mass loss and solids gain.

The Pareto diagrams show the loss of mass was the only parameter observed that was not influenced by the interaction between the two independent variables. The solution concentration and temperature were the factors that most influenced statistically the dehydration of banana peels, with positive effects at 95\% confidence. Silva et al. (2017) when performing osmotic dehydration of pequi pulp, found that the concentration of the sucrose solution was the variable that most influenced the loss of mass of the product.

It appears that the increase in the parameters water loss (WL), mass loss (ML) and solids gain (SG), showed the same behavior, being significantly influenced by the increase in the values of the input variables, sucrose concentration and temperature, a significant factor above $95 \%$ confidence, with the concentration of the dehydrating solution the factor that most influenced the increase in the values of these observed parameters. Silva et al. (2015a) also observed that sucrose concentration and temperature were the most effective factors in water loss during osmotic dehydration of the cagaita fruit (Eugenia dysenterica).

In the Pareto diagram for solids gain, it is observed that the regression of the factors was significant at $95 \%$ confidence, with the concentration of sucrose being the parameter of greatest influence on the increase of this variable during osmotic dehydration, followed by the interaction between variables and temperature. The evaluated data corroborate the study carried out by Castro et al. (2018), who also observed that sucrose concentration was the variable with the greatest influence on the incorporation of solids in fruits.

Table 6 shows the equations of the linear models for the response variables, obtained during 


\section{Macrothink

osmotic dehydration for the banana peel slices, under the different conditions of sucrose (X) and temperature $(\mathrm{Y})$. From these coefficients, the graphics of the response surfaces were generated and analyzed.

Table 6. Mathematical models of linear regression for response variables

\begin{tabular}{ll}
\hline Variables & Estimated model \\
\hline WL & $\mathrm{Z}(\mathrm{X}, \mathrm{Y})=1.4295 \mathrm{X}+1.0055 \mathrm{Y}-0.0115 \mathrm{XY}-46.1061$ \\
$\mathrm{ML}$ & $\mathrm{Z}(\mathrm{X}, \mathrm{Y})=0.8895 \mathrm{X}+0.5305 \mathrm{Y}-0.0032 \mathrm{XY}-21.5004$ \\
$\mathrm{SG}$ & $\mathrm{Z}(\mathrm{X}, \mathrm{Y})=0.5415 \mathrm{X}+0.4765 \mathrm{Y}-0.0083 \mathrm{XY}-24.6961$ \\
\hline
\end{tabular}

Note: $\mathrm{X}$ : sucrose concentration $\left({ }^{\circ} \mathrm{Brix}\right)$; Y: temperature $\left({ }^{\circ} \mathrm{C}\right)$.

Figure 2 shows the response surfaces obtained for the variables of water loss, mass and solids gain for the osmotic dehydration of banana peel slices that presented statistically significant models ( $\mathrm{Fc} \geq \mathrm{Ftab})$.
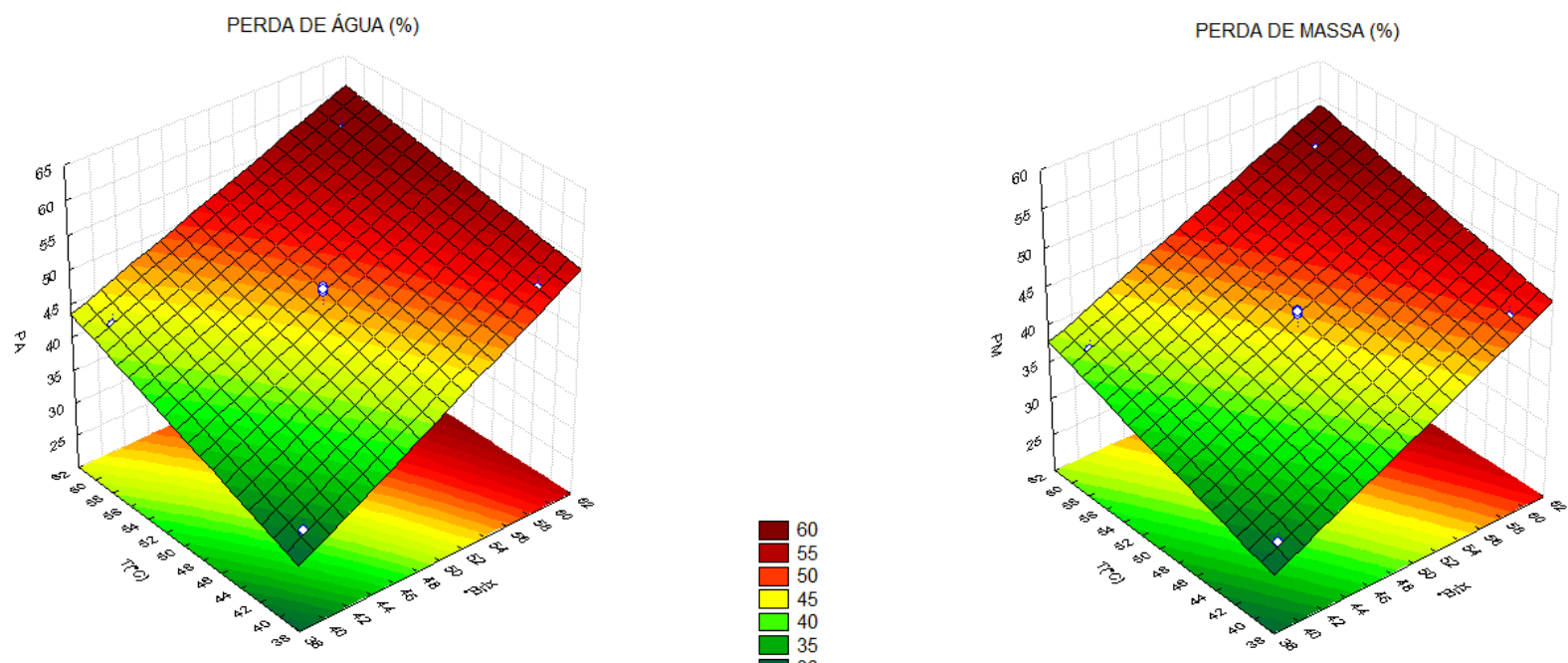


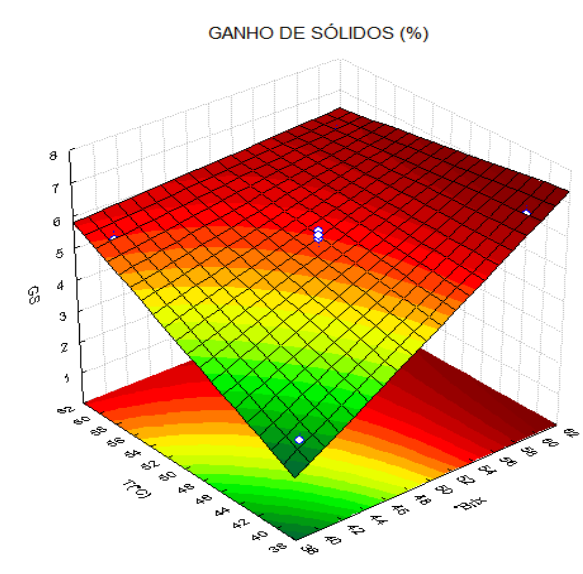

Figure 2. Response surfaces for the variables water loss, mass loss and solid gain of banana peels, as a function of sucrose concentration and temperature of the osmotic solution

According to the data evaluated in the factorial design $2^{2}$, the sucrose concentration and the temperature in the process significantly influenced the response variables in the osmotic dehydration of banana peels. It was found that the increase of these factors increases the loss of mass and water in the system, and, consequently, reduces the water activity of the samples. During the experimental tests it was noticed that in 240 minutes of process there was a significant loss of water with greater aggregation of solids in the samples.

Figure 3 presents an optimized region of the factorial design in the contour surfaces of the response variables, water loss, mass loss and solids gain, identified by the upper right region, of a darker color, where the input variables concentration ( $\left.{ }^{\circ} \mathrm{Brix}\right)$ and temperature $\left({ }^{\circ} \mathrm{C}\right)$ are more intense. Taking into account the effects observed during the osmotic dehydration of banana peels, and in view of the main objective of the food, which is to increase its shelf life, it was defined that assay $4\left(60 \mathrm{Brix}\right.$ and $\left.60{ }^{\circ} \mathrm{C}\right)$ would be the better condition of the process, as it presented higher concentrations of sucrose and temperature. 


\section{Macrothink}
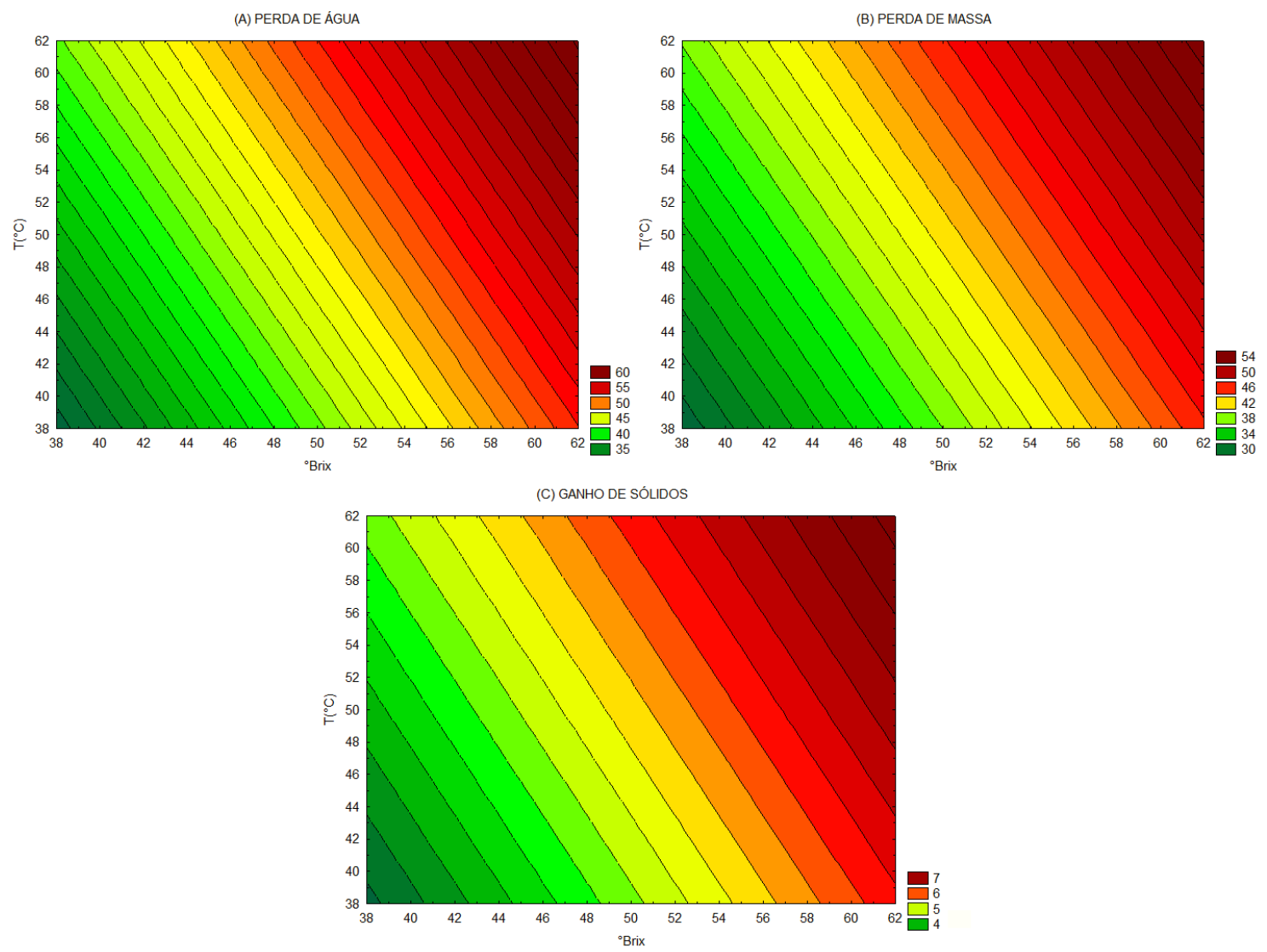

Figure 3. Contour curve of response variables in the optimized planning region

Table 7 shows the average results and the deviations of the physical-chemical parameters of the dehydrated banana peels in the best condition of osmotic dehydration ("optimized" condition). 


\section{IIMacrothink}

Table 7. Characterization of dehydrated banana peel in the best condition of osmotic dehydration

\begin{tabular}{|c|c|}
\hline Parameters & $\begin{array}{l}\text { Mean } \pm \text { Standard } \\
\text { deviation }\end{array}$ \\
\hline $\mathrm{pH}$ & $5.27 \pm 0.058$ \\
\hline Total soluble solids $\left({ }^{\circ} \mathrm{Brix}\right)$ & $16.05 \pm 0.050$ \\
\hline TSS/TTA ratio & $44.95 \pm 0.050$ \\
\hline $\begin{array}{l}\text { Total titratable acidity (\% ácido } \\
\text { málico) }\end{array}$ & $0.357 \pm 0.027$ \\
\hline Ascorbic acid (mg/100g de amostra) & $1.395 \pm 0.089$ \\
\hline Water content (\%b.u $\left.{ }^{1}.\right)$ & $43.14 \pm 0.031$ \\
\hline Ashes $(\%)$ & $1.02 \pm 0.015$ \\
\hline Total solids (\%) & $56.86 \pm 0.031$ \\
\hline Reducing sugars $(\mathrm{g} / 100 \mathrm{~g})$ & $6.38 \pm 0.165$ \\
\hline Water activity (wA) & $0.927 \pm 0.001$ \\
\hline $\mathrm{L}^{*}$ & $49.22 \pm 0.095$ \\
\hline$a^{*}$ & $6.03 \pm 0.023$ \\
\hline$b^{*}$ & $24.67 \pm 0.044$ \\
\hline
\end{tabular}

Note: ${ }^{1}$ wet base.

After the osmotic dehydration process, there was a decrease in the average value obtained for the $\mathrm{pH}$ in relation to fresh banana peels, 5.53 to 5.27 and an increase in the acidity content in terms of malic acid, from 0.168 to $0.357 \%$. The same behavior was verified by Aragão et al. (2017) when monitoring the $\mathrm{pH}$ in the osmotic dehydration of slices of mangoes of the espada variety.

As expected, there was an increase in the content of soluble solids throughout the process due to the incorporation of solids. There was an increase in acidity in the slices of banana peels, so the ratio TSS / TTA generated greater results when compared to those obtained in fresh peels. 


\section{MInstitute ${ }_{\text {Mnk }}^{\text {Macrothink }}$}

The ascorbic acid content varied between 1.415 and $1.395 \mathrm{mg}^{100 \mathrm{~g}^{-1}}$. This reduction occurred due to the instability of the compound, which oxidizes easily in contact with oxygen and degrades with increasing temperature. The reduction in the ascorbic acid content in banana peels was not as significant compared to the study of the effect of osmotic dehydration conditions on araçá-pê raisins carried out by Paglarini et al. (2015), who found a loss of $87.3 \%$ in the conditions of $50{ }^{\circ}$ Brix and $60{ }^{\circ} \mathrm{C}$.

Analyzing the values of water content and water activity obtained at the end of the process, there is a considerable reduction in the water content of the samples, from 84.56 to $43.14 \%$, and thus significantly altering the water activity from 0.966 to 0.927 . Silva et al. (2015) obtained similar results of water activity when using forage palm (Opuntia fícus-indica Mill), under the same conditions studied $\left(60^{\circ}\right.$ Brix and $\left.60{ }^{\circ} \mathrm{C}\right)$, of 0.991 for fresh samples and approximately 0.720 after osmotic dehydration.

Total solids ranged from 15.44 to $56.86 \%$, for samples with and without osmotic treatment. Because of the reduction in water content, there was a greater aggregation of nutrients, allowing greater amounts of solids. The dehydrated samples had ash content lower than the values determined in natura. As found by Queiroz et al. (2008), this reduction is due to the solubility of the minerals present in the sample with the dehydrating solution.

Comparing the initial color parameters with those determined for the osmo-dehydrated banana peel slices, there is a reduction in the attributes of brightness $\left(\mathrm{L}^{*}\right)$, red $\left(\mathrm{a}^{*}\right)$ and yellow intensity $\left(b^{*}\right)$. It is worth noting that even with the heat treatment of enzymatic inactivation the slices darkened after the process, in terms of luminosity, from 56.09 to 49.22 , in the intensity of red, with average values of 7.44 to 6.03 , and a reduction in yellow intensity from 40.45 to 24.67 .

The banana peels from the best condition of osmotic dehydration (assay $4-60{ }^{\circ}$ Brix and $60{ }^{\circ} \mathrm{C}$ ) were dehydrated in an oven with air circulation at $60{ }^{\circ} \mathrm{C}$, to perform the drying kinetics curve and in Table 8 are the estimated values of the constants of the mathematical models of Page, Henderson \& Pabis and Midilli are expressed, as well as the mean square deviations (MSD) and the coefficients of determination $\left(\mathrm{R}^{2}\right)$.

Table 8. Parameters, coefficients of determination $\left(\mathrm{R}^{2}\right)$ and mean square deviations (MSD) of the models adjusted to the drying kinetics of banana peels of the optimized condition

\begin{tabular}{lllllll}
\hline \multirow{2}{*}{ Model } & \multicolumn{2}{l}{ Parameters } & & \multirow{2}{*}{$\mathrm{R}^{2}$} & MSD \\
\cline { 2 - 5 } & $\mathrm{k}$ & $\mathrm{n}$ & $\mathrm{a}$ & $\mathrm{b}$ & & \\
\hline Page & 0.7268 & 0.8491 & - & - & 0.9967 & 0.0102 \\
\hline Henderson \& Pabis & 0.6661 & - & 0.9627 & - & 0.9939 & 0.0156 \\
\hline Midilli & 0.7690 & 0.8058 & 1.036 & 0.0004 & 0.9980 & 0.0299 \\
\hline
\end{tabular}

Analyzing the obtained parameters, a small variation is observed for the mathematical 
constants " $k$ ", " $n$ " for the Page and Midilli models, which presented the highest determination coefficients. Corrêa et al. (2007), refers to the constants k and n as representing the effects of conditions external to dehydration and the internal resistance of the samples, respectively, for the drying process. Comparing the evaluated models, it can be said that the Page model was the one that best fitted the drying curve, with high $\mathrm{R}^{2}$ and less quadratic deviation. Monteiro et al. (2020) when also performing the drying kinetics of osmotically dehydrated eggplant cubes, observed that the Page model was the one with the highest determination coefficients $\left(\mathrm{R}^{2}\right)$ and the lowest values of the chi-square function at all temperatures analyzed.

Figure 4 shows the convective drying kinetics curve of banana peels, at a temperature of $60{ }^{\circ} \mathrm{C}$ adjusted to Page's mathematical model.

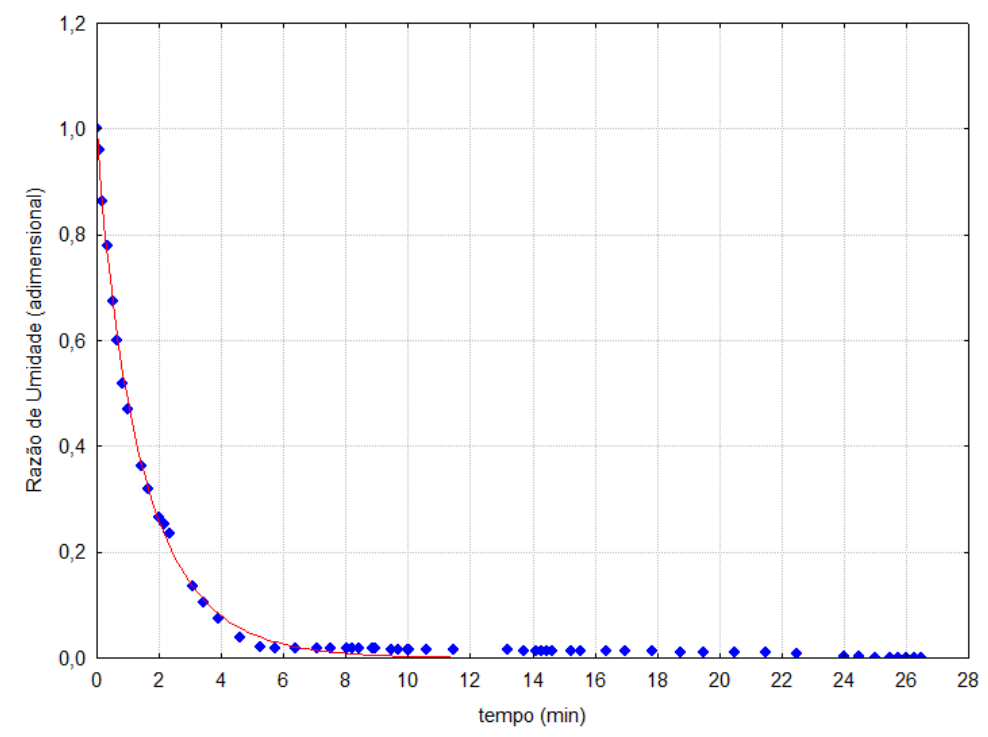

Figure 4. Drying curves of banana peels adjusted by the Page model

It can be seen through Figure 4, that the first 4 hours of drying were quite effective in reducing large amounts of water, then it appears that the curve reaches the most stable level of dehydration where the variation of water removed is minimal. The drying process proceeded for 26.5 hours until reaching constant mass.

The Fick's diffusion model was applied to determine the effective diffusivity (Def), considering the geometry of flat plates, obtaining a value of $2.2 \times 10^{-8} \mathrm{~m}^{2} \mathrm{~s}^{-1}$ and determination coefficient $\left(\mathrm{R}^{2}=0.9898\right)$. This low value of diffusivity during the drying of the peels, can be attributed to the fact that the sugar content absorbed by the samples prevents the outflow of greater water flow per unit of time. Aires et al. (2016), when performing the drying kinetics of osmotically dehydrated guavas at 40 and $50{ }^{\circ}$ Brix, obtained diffusivity values ranging from 2.75 to $3.89 \times 10^{-10} \mathrm{~m}^{2} \mathrm{~s}^{-1}$.

Table 9 shows the results of the physical-chemical parameters determined after the treatment of osmotic dehydration and convective drying, in the respective times: zero (considered the start of storage), fifteen and thirty days of storage. 


\section{MInstitute ${ }_{\text {Mntw }}^{\text {Macrothin }}$}

Journal of Agricultural Studies

ISSN 2166-0379

2020, Vol. 8, No. 4

Table 9. Average values of the physical-chemical parameters of banana peels after osmotic and convective dehydration during storage

\begin{tabular}{lccc}
\hline \multirow{2}{*}{ Parameters } & \multicolumn{3}{c}{ Storage (days) } \\
\cline { 2 - 4 } & 0 & 15 & 30 \\
\hline $\mathrm{pH}$ & $5.30 \mathrm{~b}$ & $5.51 \mathrm{a}$ & $5.52 \mathrm{a}$ \\
TSS ( ${ }^{\circ}$ Brix) & $66.67 \mathrm{a}$ & $66.67 \mathrm{a}$ & $66.33 \mathrm{a}$ \\
Ratio (TSS/TTA) & $57.71 \mathrm{a}$ & $56.61 \mathrm{a}$ & $56.26 \mathrm{a}$ \\
Total Titratable Acidity (\% malic acid) & $1.76 \mathrm{~b}$ & $1.72 \mathrm{a}$ & $1.72 \mathrm{a}$ \\
Ascorbic acid (mg/100g of sample) & $1.47 \mathrm{a}$ & $1.37 \mathrm{ab}$ & $1.23 \mathrm{~b}$ \\
Water content (\% w.b.) & $16.67 \mathrm{a}$ & $16.72 \mathrm{a}$ & $16.74 \mathrm{a}$ \\
Ashes (\%) & $1.72 \mathrm{a}$ & $1.73 \mathrm{a}$ & $1.73 \mathrm{a}$ \\
Total Solids (\%) & $83.33 \mathrm{a}$ & $83.28 \mathrm{a}$ & $83.26 \mathrm{a}$ \\
Reducing Sugars (g/100g) & $6.87 \mathrm{a}$ & $6.36 \mathrm{~b}$ & $6.30 \mathrm{~b}$ \\
Water activity & $0.703 \mathrm{~b}$ & $0.717 \mathrm{~b}$ & $0.758 \mathrm{a}$ \\
L* & $38.19 \mathrm{c}$ & $38.60 \mathrm{~b}$ & $39.26 \mathrm{a}$ \\
$\mathrm{a}^{*}$ & $8.04 \mathrm{a}$ & $7.92 \mathrm{~b}$ & $7.25 \mathrm{c}$ \\
$\mathrm{b}^{*}$ & $19.61 \mathrm{a}$ & $18.74 \mathrm{~b}$ & $17.36 \mathrm{c}$ \\
\hline
\end{tabular}

Note: Means followed by the same letter on the lines do not differ statistically according to the Tukey test at the 5\% probability level.

Table 9 shows an increase in $\mathrm{pH}$ and a reduction in the acidity of the sample between the beginning of storage and after the period of 15 days, with a statistically significant difference at a level of 5\% probability, whose $\mathrm{pH}$ varied from 5.30 at 5.51 and acidity from 1.76 to $1.72 \%$. There was no significant difference regarding these parameters during the period of 15 and 30 days of storage. According to Pegoraro et al. (2016), the reduction in the acidity of the fruits during the storage period occurs due to the degradation and volatilization of organic acids. Santos et al. (2015), when producing green banana flour, obtained a pH of 5.78.

Regarding soluble solids, there was an increase after dehydration, due to the incorporation of sucrose in the osmotic process. Evaluating the results obtained in comparison with Nunes (2017), who evaluated the properties of the banana flour of the Madeira variety, it is possible to verify that the peels after the osmo-convective process showed values close to those of the dehydrated fruit pulp flour, $71.12{ }^{\circ}$ Brix.

There was no significant difference in the content of soluble solids during storage, which showed values from 66.67 to $66.73{ }^{\circ}$ Brix. However, the reduction of the acidity of the 
product during storage caused an increase in the values of the ratio parameter, which ranged from 37.88 to 38.91. According to Morgado et al. (2019), the ratio parameter can express the degree of sweetness of the product and that it is common to increase this parameter during fruit storage, which occurs due to the reduction of acidity and an increase in the concentration of soluble solids.

In terms of ascorbic acid concentration, it can be said that the osmo-convective dehydration process preserved the quantities with respect to fresh, ranging from 1.415 to $1.47 \mathrm{mg} .100 \mathrm{~g}^{-1}$. After the storage period, there was a decrease in the values of ascorbic acid, which according to Oliveira et al. (2015) is caused by oxidation reactions. Factors such as the applied dehydration method, storage time and packaging used directly influence the oxidation reactions to which the product is susceptible. Reis et al. (2017) observed an increase in the concentration of vitamin $\mathrm{C}$ after dehydration of acerola cherry. The same authors also found that the final concentration of this vitamin was lower when they used lower temperatures and longer periods of time, since the longer exposure time in drying degrades the nutritional constituents of food.

The osmotic process followed by convective drying was effective in reducing $80.3 \%$ of the water content and $29.41 \%$ in the water activity of peels in natura. The water content values did not differ statistically and varied from 16.67 to $16.74 \%$, after 30 days. Lower values regarding water content (13.99 to $14.54 \%$ ) were presented by Gonçalves et al. (2017) when performing the convective drying of banana peels, using temperatures of 55,65 and $75{ }^{\circ} \mathrm{C}$. Machado et al. (2019) when assessing the stability of the physalis pulp did not observe any significant difference in relation to the moisture content during the 120-day storage period. The value of water activity at the beginning of the storage period was 0.703 and increased to 0.758 at the end of dehydration, this difference being statistically significant.

There was no significant difference regarding the ash content during the storage of dehydrated banana peels, which showed values from 1.72 to $1.73 \%$. Pagani et al. (2017) when analyzing flours obtained from drying sweet potatoes, they also found that the ash content of the samples was practically confirmed during their storage. Analyzing the results obtained for reducing sugars (RS), there is an increase in concentration after the osmo-convective process. In stability, only the average ( 0 days) differed statistically from its 15 and 30 day averages, with a reduction during the storage period. Considerable result compared to that found by Silva (2013), in banana peel flour, which presented a concentration of $5.75(\mathrm{~g} / 100 \mathrm{~g})$.

Evaluating the color parameters, it is observed that the slices darkened with the storage time, due to the increase in luminosity (*L), but also due to the red $\left(+\mathrm{a}^{*}\right)$ and yellow $\left(+\mathrm{b}^{*}\right)$ intensity values found. These parameters showed small variations, but differed statistically between the averages obtained. Similar behavior was observed by Aranha et al. (2017) when evaluating the stability of fruit flours during storage, the authors associated the color changes in the product to the enzymatic browning processes, Maillard reaction and factors such as changes in $\mathrm{pH}$, acidity and storage temperature. 


\section{Conclusion}

The banana peels used in the experiments had a high water content and reasonable amounts of carbohydrates and ashes. Under the conditions in which the assays were carried out, it can be concluded that the sucrose concentration and the temperature had significant effects on the process with assay 4, under the conditions of sucrose concentration ( $60{ }^{\circ}$ Brix) and temperature $\left(60{ }^{\circ} \mathrm{C}\right)$, providing greater water losses and incorporation of solids. The osmoconvective dehydration process resulted in a greater incorporation of total soluble solids and higher percentages of total solids in the peels.

Page's mathematical model showed the best fit to the experimental data, as it showed a coefficient of determination $\left(\mathrm{R}^{2}\right)$ greater than 0.99 and a low mean squared deviation (MSD). The effective diffusivity showed a coefficient of determination $\left(\mathrm{R}^{2}\right)$ greater than 0.98 . The drying process provided product conservation, reducing the water content and activity. And the physical and physical-chemical parameters analyzed during the storage had small changes during the period of 30 days of storage.

\section{References}

Aires, J. E. F., da Silva, W. P., Cavalcante de Almeida Farias Aires, K. L., Júnior, A. F. da S., de Castro, D. S., \& Silva, C. M. D. P. da S. (2016). Guava Osmotic Dehydration: Description by Two-Dimensional Diffusion Models Considering Shrinkage and Variations in Process Parameters. International Journal of Food Engineering, 12(6). https://doi.org/10.1515/ijfe-2016-0056

Almeida, R., Santos, N., Pereira, T., Queiroga, A., Silva, V., Ribeiro, V., Borges, E. (2020). Azuki bean drying kinetics: mathematical modeling and thermodynamic properties. Research, Society and Development, 9(3), e27932316. https://doi.org/10.33448/rsd-v9i3.2316

Aragão, P. P., Loss, R. A., Silva, S. S., \& Guedes, S. F. (2017). Avaliação do potencial de utilização de pré-tratamento osmótico na produção de manga desidratada. Revista Destaques Acadêmicos, 9(4), 1-13. https://doi.org/10.22410/issn.2176-3070.v9i4a2017.1671

Aranha, J. B., Nigri, T. C., Martin, J. G. P., \& Spoto, M. H. F. (2017). Effect of gamma radiation on the microbiological and physicochemical parameters and on the phenolic compounds of a fruit residue flour during storage. Brazilian Journal of Food Technology, 20, 1-10. https://doi.org/10.1590/1981-6723.12316

Astricini, A., Santos, L. O., Deliza, R., Coelho, E. F., \& Rodrigues, M. G. V. (2015). Caracterização pós-colheita e sensorial de genótipos de bananeiras tipo prata. Revista Brasileira de Fruticultura, 37(1), 27-37. https://doi.org/10.1590/0100-2945-058/14

Benassi, M. D., \& Aantunes, A. J. (1998). A comparison of metaphosphoric and oxalic acids as extractants solutions for the determination of vitamin $\mathrm{C}$ in selected vegetables. Arquivos de Biologia e Tecnologia, 31(4), 507-503.

Bozkir, H., Ergun, A. R., Serdar, E., Metin, G., \& Baysal, T. (2019). Influence of ultrasound and osmotic dehydration pretreatments on dryingand quality properties of persimmon fruit. 
Ultrasonics Sonochemistry, 54, 135-141. https://doi.org/10.1016/j.ultsonch.2019.02.006

Brasil, Instituto Adolfo Lutz. (2008). Métodos físico-químicos para análise de alimentos (4th ed., Volume 1, p.1020). São Paulo: Instituto Adolfo Lutz.

Carvalho, A. V., Seccadio, L. L., Mourão Júnior, M., \& Nascimento, W. M. O. (2011). Qualidade Pó-colheita de Cultivares de Bananeira do Grupo "Maçã', na Região de Belém PA. Revista Brasil Fruticultura, 33(4),1095-1102. https://doi.org/10.1590/S0100-29452011000400007

Castilho, L. G., Alcântara, B. M., \& Clemente, E. (2014). Desenvolvimento e análise físico-química da farinha da casca, da casca in natura e da polpa de banana verde das cultivares maçã e prata. Revista E-xacta, 7(2), 107-114. https://doi.org/10.18674/exacta.v7i2.1353

Castro, D. S., Silva, W. P., Gomes, J. P., Aires, J. E. F., Farias Aires, K. L. C. A., \& Júnior, A. F. S. (2018). Desenvolvimento e avaliação sensorial de goiaba-passa desidratada osmoticamente. Brazilian Journal of Food Technology, 21, e2016013. https://doi.org/10.1590/1981-6723.1316

Chen, J., Li, F., Li, Y., Wang, Y., Wang, C., Yuan, D., \& Jiang, Y. (2019). Exogenous procyanidin treatment delays senescence of harvested banana fruit by enhancing antioxidant responses and in vivo procyanidin content. Postharvest Biology and Technology, 158, 110999. https://doi.org/10.1016/j.postharvbio.2019.110999

Corrêa, P. C., Resende, O., Martinazzo, A. P., Goneli, A. L., \& Botelho, F. M. (2007). Modelagem matemática para a descrição do processo de secagem do feijão (Phaseolus vulgaris L.) em camadas delgadas. Engenharia Agrícola, 27(2), 501-510. https://doi.org/10.1590/S0100-69162007000300020

Gonçalves, J. Q., da Silva, M. A. P., Plácido, G. R., Caliari, M., Silva, R. M., Moura, L. C., \& Souza, D. G. (2017). Secagem da casca e polpa da banana verde (Musa acuminata): Propriedades físicas e funcionais da farinha. Global Science and Technology, 9(3).

Leite, G. A., Medeiros, E. V., Mendonça, V., Moraes, P. L. D., Lima, L. M., \& Xavier, I. F. (2010). Qualidade Pós-colheita da Banana 'Pacovan' Comercializada em Diferentes Estabelecimentos no Município de Mossoró-RN. Revista Brasileira de Ciências Agrárias, 5(3), 322-327. https://doi.org/10.5039/agraria.v5i3a614

Machado, T. F., Monteiro, E. R., \& Tiecher, A. (2019). Estabilidade química, físico-química e antioxidante de polpa de Physalis pasteurizada e não pasteurizada sob congelamento. Brazilian Journal of Food Technology, 22(0). https://doi.org/10.1590/1981-6723.14917

Miller, G. L. (1959). Use of dinitrosalicylic acid reagent for determination of reducing sugar. Analytical Chemistry, Washington, 31(3), 426-428. https://doi.org/10.1021/ac60147a030

Monteiro, S., Monteiro, S., Santos, N., Barros, S., Cruz, O., Martins, L., \& Gomes, J. (2020). Aplicação de processos combinados osmótico e secagem em air fryer em berinjelas condimentadas com hibisco. Research, Society and Development, $9(3)$. 
https://doi.org/10.33448/rsd-v9i3.2267

Morgado, C. M., Guariglia, B. A., Trevisan, M. J., Façanha, R., Jacomino, A. P., Corrêa, G., \& Cunha Junior, L. C. (2019). Quality assessment of jabuticabas (cv. sabará), submitted to refrigerated storage and conditioned in different packaging. Revista Interdisciplinar da $\begin{array}{lllll}\text { Universidade } \quad \text { Federal } & \text { Do } & \text { Tocantins, } & \text { 6(2), }\end{array}$ https://doi.org/10.20873/uft.23593652201962p18

Neris, T. M., Silva, S. S., Loss, R. A., Carvalho, J. W. P., \& Guedes, S. F. (2018). Avaliação físico-química da casca de banana (Musa spp.) in natura e desidratada em diferentes estádios de maturação. Ciência e Sustentabilidade, $\quad 4(1), \quad$ 5-21. https://doi.org/10.33809/2447-4606.4120185-21

Nunes, S. M. G. C. (2017). Estudo das propriedades da farinha de banana da Madeira (Dwarf Cavendish) e a sua incorporação em trufas de chocolate. Lisboa: ISA. p. 598.

Oliveira, A. da S., Figueirêdo, R. M. F. de, Queiroz, A. J. de M., \& Brito, J. G. de. (2015). Estabilidade da polpa do Cereus jamacaru em pó durante o armazenamento. Revista Brasileira de Engenharia Agrícola e Ambiental, 19(2), 147-153. https://doi.org/10.1590/1807-1929/agriambi.v19n2p147-153

Pádua, H. C., Silva, M. A. P., Souza, D. G., Moura, L. C., Plácido, G. R., Couto, G. V. L., \& Caliari, M. (2017). Iogurte Sabor Banana (Musa AAB, Subgrupo Prata) Enriquecido com Farinha de Casca de Jabuticaba (Myrciaria Jabuticaba (Vell.) Berg.). Global Science and Technology, 10(1), 889-104.

Pagani, A. A. C., \& Santos, S. (2017). Study of the physical-chemical stability of two varieties of sweet potato (Ipomea potato $l$.) after the drying process and during the storage. Intelectual Property and Technology, 8(1), 380-390.

Paglarini, C. S., Silva, F. S., Porto, A. G., Zela, S. P., Leite, A. L. M. P., \& Furtado, G. F. Efeito das condições de desidratação osmótica na qualidade de passas de araçá-pêra. Revista Brasileira de Tecnologia Agroindustrial, 9(2), 1945-1961. https://doi.org/10.3895/rbta.v9n2.1961

Panesar, P. S., Kaur, R., Singla, G., \& Sangwan, R. S. (2016). Bio-processing of agro-industrial wastes for production of food-grade enzymes: progress and prospects. Applied Food Biotechnol, 3(4), 208-227.

Papazoglou, D. D., \& Katsanidi, E. (2019). Diffusion coefficients and volume changes of beef meat during osmotic dehydration in binary and ternary solutions. Food and Bioproducts Processing, 116, 10-19. https://doi.org/10.1016/j.fbp.2019.04.007

Pegoraro, C., Storch, T.T., Crizel, G. R., Ferreira, W. A., \& Girardi, C. L. (2016). Controlled atmosphere associated with 1-methylcyclopropene in the preservation of 'Tewi' kiwifruit quality Brazilian Journal Food Technology, 19, 1-7. https://doi.org/10.1590/1981-6723.7814

Porto, M. A. L., Guerra, N. B., Vasconcelos, M. A. S., Siqueira, A. M. O., \& Andrade, S. A. C. (2014). Otimização da Desidratação Osmótica de Uva Crimson Seedless. Revista Ciência 
Agronômica, 45(2), 249-256. https://doi.org/10.1590/S1806-66902014000200004

Queiroz, V. A. V., Berbert, P. A., Molina, M. A. B., Gravina, G. A., Queiroz, L. R., \& Silva, J. A. (2008). Qualidade nutricional de goiabas submetidas aos processos de desidratação por imersão impregnação e secagem complementar por convecção. Ciência e Tecnologia de Alimentos, 48(5), 756-770. https://doi.org/10.1590/S0101-20612008000200010

Rahaman, A., Zeng, X. A., Kumari, A., Rafiq, M., Siddegg, A., Manzoor, M. F., Baloch, Z., \& Ahmed, Z. (2019). Influence of ultrasound-assisted osmotic dehydration on texture, bioactive compounds and metabolites analysis of plum. Ultrasonics Sonochemistry, 58, 1-11. https://doi.org/10.1016/j.ultsonch.2019.104643

Reis, D. R., Figueiredo Neto, A., Ferraz, A. V., \& Freitas, S. T. (2017). Production and storage stability of acerola flour dehydrated at different temperatures. Brazilian Journal of Food Technology, 20, 1-7. https://doi.org/10.1590/1981-6723.8315

Santos, L. F., Lehner, M. T., Freitas, A. F., \& Ries, E. F. (2015). Caracterização de farinhas de banana caturra e utilização em biscoito dietético. Revista Magistra, 27(2), 145-158.

Silva, C. D. M., Pires, C. R. F., Lima, J. P., Pereira, A. S., \& Silva, C. A. (2015a). Desidratação osmótica para obtenção de cagaita passa. Journal of Bioenergy and Food Science, 2(4), 226-233. https://doi.org/10.18067/jbfs.v2i4.82

Silva, D. F., Rigueto, C. V. T., Loss, R. A., Guedes, S. F., \& Carvalho, J. W. P. (2017). Tratamento osmótico na obtenção de lascas da polpa de pequi (Caryocar brasiliense) desidratadas. Natural Resources, $\quad 7(1), \quad$ 1-8. https://doi.org/10.6008/SPC2237-9290.2017.001.0001

Silva, E. T., Silva, E. C. O., Gusmão, R. P., Lopes, J. D., \& Gusmão, T. A. S. (2015b). Modelagem matemática da desidratação osmo-convectiva da palma forrageira (Opuntia fícus-indica Mill) utilizando soluções mistas. Revista Verde, 10(4), 39-48. https://doi.org/10.18378/rvads.v10i4.3489

Silva, L. R. M. S. (2013). Aproveitamento da casca de banana para produção de farinha destinada à formulação de biscoitos [dissertação]. João Pessoa: Universidade Federal da Paraíba, 2(1), 3.

Silva, S. N., Gomes, J. P., Santos, N. C., Matos, J. D. P., Moraes, M. S., Silva, R. M., ... Silva, V. M. A. (2019). Physicochemical and colorimetric composition of mandacaru fruit pulp at different maturation stages. Sylwan, 163(4), 282-291.

Sulistyawati, I., Dekker, M., Fogliano, V., \& Verkerk, R. (2018). Osmotic dehydration of mango: Effect of vacuum impregnation, high pressure, pectin methylesterase and ripeness on quality. Food Science and Technology, 98, 179-186. https://doi.org/10.1016/j.lwt.2018.08.032

Taco. (2011). Tabela brasileira de composição de alimentos. 4ed. Revisada e ampliada. Campinas, SP: Unicamp.

Viana, E. S., Reis, R. C., Sena, L. O., Santos Júnior, M. B., \& Silva, P. N. R. (2017). Produção 


\section{Macrothink}

Journal of Agricultural Studies

ISSN 2166-0379 2020, Vol. 8, No. 4

de bananas-passa com frutos de variedades melhoradas e avaliação da qualidade físico-química e sensorial. Boletim CEPPA, 35(1), 1-10. https://doi.org/10.5380/cep.v35i1.55944

Vu, H. T., Scarlett, C. J., \& Vuong, Q. V. (2019). Changes of phytochemicals and antioxidant capacity of banana peel during the ripening process; with and without ethylene treatment. Scientia Horticulturae, 253, 255-262. https://doi.org/10.1016/j.scienta.2019.04.043

\section{Copyright Disclaimer}

Copyright for this article is retained by the author(s), with first publication rights granted to the journal.

This is an open-access article distributed under the terms and conditions of the Creative Commons Attribution license (http://creativecommons.org/licenses/by/4.0/). 